\title{
Child Sexual Victimisation: Ethnographic Stories of Stranger and Acquaintance Grooming
}

\section{Andy Williams}

\begin{abstract}
In recent years research into child sexual offending has highlighted 'grooming' as an important part of the offence chain. Topics that have come to dominate the research agenda have focused on the offenders' perspectives, psychological models of offending behaviour and how child sex offenders (CSOs) are managed and treated in local communities (for example, through Multi-Agency Public Protection Arrangements). Whilst these studies are extremely important, one area that has suffered from a lack of research and visible debate is how victims, their families and local communities experience grooming in situ and on a day-to-day basis. Using observational, interview and document data collected from an ethnography of a south-east coast community that houses a number of child sex offenders, this article examines the strategies used by strangers and acquaintances when grooming the local environment, significant others and children. Importantly, these grooming experiences are articulated from the perspective of the victims and their families. In doing so, the article discusses the implications that these experiences have for understanding offender-victim behaviours.
\end{abstract}

\section{Introduction}

Over the last twenty years there has been growing concern regarding CSOs and their activities in local communities (Janus, 2006; Williams, 2006; Zott, 2008; Thomas, 2011; McAlinden, 2102). Exaggerated and distorted images and symbolism regarding paedophiles are given high visibility through a symbiotic relationship between claims-making moral entrepreneurs and the mass media (Becker, 1963; Best, 1995 and 2001; Kitzinger, 1999; 2004; Thompson and Williams, 2014). The most influential moral entrepreneurial group are politicians, who have responded to the burgeoning culture of fear (Furedi, 1997) by creating large numbers of laws and criminal justice policies that are designed to punish, rehabilitate and 'manage' these offenders in local communities (Nash, 2006; Wacquant, 2009). At the same time, a growing body of research has looked at explaining child sexual offending (e.g. Hudson, 2005; Ward et al, 2006; Beech et al, 2009; McAlinden, 2012) and the ways the risk levels of these 'offenders' are managed by police and probation (Ireland et al, 2009; Nash, 2006; Nash and Williams, 2010). Whilst this body of research is both important and useful, what has received only sporadic attention is the pre-offence grooming behaviour and an understanding of the dynamics whereby such behaviour changes the 'victim relationship' to an overtly abusive one (Berliner and Conte, 1990: 2). It is of great importance to understand how victims of child abuse are approached and groomed as part of their routine activities (Felson, 2008), as this enables a more holistic understanding of the interaction between offender, victim and the circumstances and context of the offence that takes place (Scott, 1977; Nash and Williams, 2008). Unfortunately, the central problem facing anyone wishing to prevent child sexual abuse is that the pre-offence behaviours (grooming), are usually identified only after the abuse has taken place and with the benefit of hindsight. Once abuse is disclosed, innocent acts such as buying sweets and treats, and spending time with children and their families suddenly take on a different meaning. Indeed, retrospective analysis of behaviours after the sexual offence has occurred is much easier than 
prospective identification (Craven et al, 2006: 292). Previous research has considered this important aspect of the offence chain by examining the strategies used by CSOs during the grooming process (Berliner and Conte, 1990; Elliott et al, 1995). A further problem is that the very nature of sexual offending is heterogeneous and grooming itself is a very nuanced concept involving different ages and genders of both victims and offenders; different relationships between victim and offender; as well as varying locations and levels of contact (Elliott et al, 1995: 581-582). An ethnographic approach using the perspectives of victims and their families is one potential way to reduce these problems, by providing a micro-contextual analysis of seemingly innocent behaviours.

This article uses ethnographic data to support a micro-level analysis of child sexual grooming by looking at the contextual-dynamics from the perspective of families who have had contact with 'groomers'. In doing so, it concentrates on stranger and acquaintance grooming only (i.e. from predatory $\mathrm{CSO}$ ). This is not to downplay the fact that family and close relatives commit a proportion of sexual offending against children (e.g. Elliott et al, (1995: 581) put parental abuse at around 32\%). Instead, it attempts to highlight the fact that 'predatory paedophilia' is more nuanced as the grooming behaviours involved subtly change the victim-offender relationship from stranger to acquaintance using the most benign forms of everyday social interaction (McAlinden, 2012).

\section{Defining and Understanding 'Grooming'}

Current research into child sexual grooming has tended to concentrate on specific areas that are largely determined by the agendas of moral entrepreneurial groups such as CEOP (Child Exploitation and Online Protection), Barnardo's and the NSPCC who tend to concentrate their claims-making activities in areas that are the most visible and profitable (in terms of maintaining the resources and jurisdictional boundaries of the organisation itself). Areas such as Internet child sexual offences (i.e. child pornography and Online grooming) and child sexual exploitation have come to the forefront in the fight against child abuse (Jenkins, 2003; Taylor and Quayle, 2003; O'Donnell and Milner, 2007; Sheldon and Hewitt, 2007; CEOP, 2011; Phoenix, 2012; Quayle and Ribisl, 2012; Berelowitz, 2013; HOCHAC, 2013). These developments in research are extremely important, and have generated some fascinating and useful knowledge on the characteristics of the offender and victim, as well as providing us with knowledge about the offence chain (Ward et al, 2006; Seto, 2007). Whilst these are all important areas to consider, the fact remains that most of these offences happen somewhere: they take place in someone s house, flat, garage, or car and in a wide variety of leisure and institutional settings which are located in a variety of community settings. Research on grooming, therefore, needs to mix the macro-vantage point of recent research with a micro-level that examines the contextual-dynamics of the pre-cursors to child sexual offending (see Finkelhor, 1984; Berliner and Conte, 1990; Elliott et al, 1995).

Grooming is a complex issue when it comes to identifying both its nature and extent. CSOs employ a number of different tactics at any given time depending on their own 'affectual states' and motivations towards offending; the type of victim they target; and the circumstances and context in which the offender and victim interact (Finkelhor, 1984; Berliner and Conte, 1990; Ward et al, 2006; Seto, 2007; Beech et al, 2009). Despite several important advances in research (Finkelhor, 1984; Berliner and Conte, 1990; Marshall and Barbaree, 1990; Elliott et al, 1995; Ward et al, 1995; Ward and Siegert, 2002; Ward et al, 2006), there is still much to learn about sexual grooming. In their 
review of the grooming literature, Craven et al (2006: 287-288) note how professionals do not agree on definitions of sexual grooming of children. Thus, many definitions exist with different elements and foci. For example, grooming has been defined as 'a course of conduct enacted by a suspected paedophile, which would give a reasonable person cause for concern that any meeting with a child arising from the conduct would be for unlawful purposes' (O'Connell, 2003: 6 cited in Craven et al, 2006: 288). Other definitions suggest it is 'the process by which a child is befriended by a would-be abuser' (Gillespie, 2002: 411 cited in Craven et al, 2006: 288); and 'the sequence of behaviours employed by the offender in order to make the victim less resistant to the eventual sexual abuse' (Sheldon and Howitt, 2007: 58-59). The first definition is problematic due to the use of the term 'paedophile' which ignores the grooming of post-pubescent children by 'ephebophiles'. Despite its cultural resonance paedophilia is a very specific clinical term (see APA, 1994), which refers to intense sexual urges towards pre-pubescent children. An ephebophile is someone who is sexually attracted to adolescents (Howitt, 1995). Whilst there are offenders whose victim criteria crosses pre and postpubertal age boundaries, evidence suggests most offenders tend to have a 'preference' for a specific age range (Elliott et al, 1995: 581).

Furthermore, many offenders tend to be gender specific. For example, Elliott et al (1995: 581) found that $72 \%$ of their sample of 91 child sex offenders targeted specific genders ( $58 \%$ female and $14 \%$ male). Where possible, it is important to identify and distinguish paedophiles from ephebophiles, as their proclivities will have a direct impact on the grooming strategies and behaviours. For example, pre-pubescent/younger children tend to have closer surveillance and guardians, whereas teenagers tend to be less restricted. Furthermore, these definitions use a range of problematic terms such as 'course of conduct', 'sequence of behaviours', and 'reasonable person'; all of which require further elucidation. In order to avoid such problems, this article employs the definition set out in Craven et $a l$, as it is one of the most comprehensive yet clearest definitions of child sexual grooming:

A process by which a person prepares a child, significant adults and the environment for the abuse of this child. Specific goals include gaining access to the child, gaining the child $s$ compliance and maintaining the child s secrecy to avoid disclosure. This process serves to strengthen the offender's abusive pattern, as it may be used as a means to justifying or denying their actions (Craven et al, 2006: 297).

\section{The Offence Chain}

The studies used here are taken from a wide range of research on child sexual offending and child grooming (Finkelhor, 1984; Berliner and Conte, 1990; Marshall and Barbaree, 1990; Elliott et al, 1995; Ward et al, 1995; Ward and Siegert, 2002). The majority of these studies used semi-structured interviews and self-report measures to ask questions from samples of victims and offenders that were identified through treatment programmes and sexual assault centers. In most cases, the information provided illustrated key factors of the offence process that indicated that, apart from opportunistic or situational offenders, grooming plays a major role in the 'offence chain'. For instance, Ward et al's (1995: 455) study used 26 incarcerated male child-molesters to 'develop a model of the offense chain based on a grounded theory analysis which examined a constructed vignette written by the offender and which described their most recent or typical offense' (1995: 455). They identified a 'micro-level' process consisting of nine stages labelled as background factors, distal planning, contact with victims, cognitive restructuring, proximal planning, sexual offence, 
cognitive restructuring, future resolutions and background factors (Ward et al, 1995; Ward et al, 2006: 249-252). Grooming practices can be linked to stages 2 to 5 of the model: stage 2, for instance, is the 'distal planning stage of the seduction process' (Ward et al, 1995: 461-462) and involves how the offender plans contact with the victim.

As grooming involves both 'planning' and 'contact' with the victim, distal planning strategies are useful for identifying grooming behaviours and why offenders are able to successfully abuse children, sometimes over long periods of time. There are three identifiable strategies that offenders use: covert/implicit, explicit and by chance/opportunistic (Ward et al, 1995: 461). Grooming is largely associated with the first two types: covert or implicit planning describes when the offender 'does not acknowledge any planning', but manipulates circumstances in order to enhance the likelihood of contact with a potential victim. The second type of planning is explicit and this involves 'deliberately initiating contact for sexual purposes' (1995: 461). Offenders engaging in explicit planning describe being in a 'positive affective state' and tend to know the victim and cultivate an intimate relationship with them (1995: 461-462). Elliott et al (1995: 584-586) found a number of core grooming behaviours that offenders used as part of the offence chain. Even the selection of the victim played an important role in grooming practices, for example, the way the child was dressed and whether the child lacked confidence and self-esteem; factors that the research has found make children more vulnerable to grooming practices (e.g. Finkelhor, 1984; Berliner and Conte, 1990; Elliott et al, 1995; McAlinden, 2012). The distal planning strategies used included 'gaining trust of the whole family' and 'using affection, understanding and love' (1995: 585). What is of particular interest in this study is that $84 \%$ of offenders interviewed stated that 'once they had developed a series of successful strategies, they approached children with that same method every time' (Elliott et al, 1995: 586).

What this research indicates is that behavioural consistency exists within many CSOs. It also highlights that grooming forms part of the offence chain and 'that an opportunity to sexually abuse a child is more likely to emerge following an act of sexual grooming' (Ost, 2004: 148).

\section{Grooming Typologies}

Despite being one of the biggest challenges facing child protection agencies, understanding the behaviours of both offenders and victims has a number of benefits. It can help both proactive crime prevention and reactive criminal investigations, as it could be used as evidence towards proving a motive of 'grooming' and 'harmful intent' (Ost, 2004: 150-151); especially if a pattern of behaviour is an established MO (modus operandi) of an offender who has a previous conviction of similar child sexual offences. Information on grooming strategies could also be useful for deciding punishment, licence conditions, and support Risk of Harm Orders (ROHOs) or Sex Offences Prevention Orders (SOPOs) applications. Finally, an understanding of grooming behaviours may be useful in developing educational materials for victims, other children in the immediate environment and local communities.

Research provides evidence of 'types' of grooming behaviour and strategies that offenders engage in. Typologies are useful for framing our understanding of complex issues and for enabling the comparison between different, yet connected categories of behaviour. Whilst it should be acknowledged that the inter-reliability between 'types' is not often statistically significant or empirically proven (e.g. see Canter et al's (2004) study of the FBI's organised/disorganised 
dichotomous typology); typologies have been useful rehabilitating child sexual offenders (e.g. the Massachusetts Treatment Centre Child Molester V3 (MTC:CM3) typology which has been developed in a clinical setting over many years - see Bartol and Bartol, 2008).

In an early study into offender-victim interaction behaviours, Canter et al (1998: 529) provided a Small Space Analysis of the interactions of sex offenders and their victims, gleaned from the police records of ' 97 recorded incidents of child sexual abuse'. One of the aims of the study was to provide empirical support for three conceptually distinct grooming themes that had previously been discussed in the literature on child sexual abuse (e.g. Finkelhor, 1984; Prentky et al, 1997; Wyre, 1997). First is the aggressive type, which was characterised by 'violence, threat and force'; second, the criminal-opportunist, which were 'one-off offences on strangers'; and finally, the intimate type, which was characterised as a 'highly intimate form of interaction' in which offenders perceived 'a relationship with their victims analogous to a conventional sexual relationship among adults' (Canter et al, 1998: 535). The intimate type is established in other research, for example, the MTC:CM3 includes an 'interpersonal type' where molesters try to develop intimate relationships with children (Bartol and Bartol, 2008); and is similar to Holmes and Holmes' 'courtship' theory (2008). The offender-victim interactions associated with the intimate type consisted of the promise of gifts/treats, reassurance, affection, desensitisation, oral sex by offender on victim and kissing (1998: $538,542-546)$. Furthermore, it was found that the 'intimate' type caused less 'harm' to their victims as the acts identified are developed as grooming strategies so they are not 'likely to be reported, identified and convicted' because they 'are used to avoid disclosure and conviction' (Craven et al, 2006: 288). Canter et al's study also found that $45 \%$ 'employed an intimate behaviour repertoire and sexual grooming behaviours' although it has been suggested that this figure is 'unrepresentative' of the general population of child sex offenders (Craven et al, 2006: 289).

More recent research has highlighted the existence of three types of child sexual grooming: selfgrooming; grooming of the social environment and significant others; and grooming of the child (Craven et al, 2006: 291-296; McAlinden, 2012). The last two in this typology are the most relevant for this current study.

\section{Methodology}

The evidence on which this article is based is taken from on an ethnographic study that started over thirteen years ago as part of my doctoral research into demonstrations against child sex offenders in a southeast coastal city (Williams, 2004). In August 2000, a small number of residents in the research site undertook a week of demonstrations to protest against the perceived problems with the then newly created MAPPP (multi-agency public protection panels) model of offender management. Across the week up to 350 residents marched to the houses of 'known' CSOs and engaged in what the historian Thompson labelled as a 'rough music' (Thompson, 1993). The subsequent societal reaction was both widespread and negatively directed towards the protestors, and consisted of exaggerated and distorted vitriolic reactions by the press, politicians, and members of various criminal justice organisations. This reaction has since been subsumed within academic folklore and the discourse of 'moral panic' (for example, see Bell, 2002; Cohen, 2003; Evans, 2003; Silverman and Wilson, 2001). However, this discourse failed to identify the true motivations behind the protest, and in doing largely ignored the protestors' own perspectives. In this case, there were very real fears 
and concerns from a number of families regarding the grooming of their children by a prolific child sex offender (for an account of these events from the demonstrators' perspective see Williams, 2004; Williams and Thompson, 2004a and 2004b; and Thompson and Williams, 2014: 211-241).

Ethnographic research is the 'first-hand experience and exploration of a particular social or cultural setting on the basis of (though not exclusively by) participant observation' (Atkinson et al, 2007:4-5). It sets out to represent as accurately as possible the process of social life from the participants' viewpoint and in the setting being investigated. The core aim is to capture the motivations and meanings of social action engaged in by other people (Atkinson et al, 2007; Hobbs, 2007; Gobo, 2008). In doing so, it uses data and methodological triangulation (Denzin, 1971) by gathering and drawing from a rich mix of qualitative and quantitative data. Ever since Robert Park inspired students to 'go out and get your hands dirty in real research' (Adler and Adler, 1998: xii), generations of ethnographers have extolled the benefits of ethnographic research and it has made a significant contribution to the understanding of crime, deviance and victimisation (Becker, 1953; Sutherland, 1956; Shaw, 1966; Liebow, 1967; Polsky, 1971; Inciardi et al, 1993; Whyte, 1995; Armstrong, 1998; Winlow et al, 2001; Bourgois, 2002; Hobbs et al, 2003; Yates, 2004; Hobbs, 2007). These and many other researchers have continued to 'get dirty' despite some intensive criticisms from the positivist paradigm, the political left and right and administrative criminology (Hobbs, 2007: 206). Most of these criticisms concern the lack of 'adequate sampling methods', and 'statistical inferential testing', as well as the inability for the 'repeat testability' of the research itself. Whilst these are valid criticisms, they often miss the point of ethnography, the benefits of which far outweigh whether the results can be generalisable to a given population. In recent years, such criticisms have found support in administrative criminology and criminal justice studies, whose dominance of the research agenda has created what Adler and Adler called 'the dark ages' of ethnography (1998: xiv). Hobbs (2007: 215) expresses this best when arguing that 'the modern criminologist's bookshelf has become overloaded with policy oriented criminal justice repair kits sitting spine to spine with a few token theoretical tomes'. He calls for ethnographers to 'delay the funeral, or at least extend the wake' (2007: 215). This study is my minor contribution to that wake.

The clearest benefit of ethnographic research is that it gives a voice to those communities who are labelled as deviant, or who are marginalised, and allows an understanding of the meaning such individuals and communities attach to their everyday lives (Becker, 1967; Hobbs, 2007; Yates, 2004). Furthermore, Hobbs' (2001: 204) review of 'deviant ethnographies' notes how the ethnographic method requires a commitment to personal observation, interaction and the witnessing of the experiences of those being studied, and because of this, it is an adaptable tool.

Research into deviant and marginalised communities usually stems from PhD students who are early career researchers and tend to take more risks (Hobbs, 2007: 214). This was certainly true in my case, as the evidence upon which this paper is based developed quite by accident. During the initial research, questions regarding the interactions between families and the subject of the main demonstration lead to conversations about the 'grooming' behaviours witnessed by the children, parents and grandparents being interviewed. In short, these grooming stories developed naturally from the research setting, following Liebow's method of capturing real-life evidence (Liebow, 1993). A 'grooming research pathway' was then developed after the original research was completed, and the interviews and discussions of this pathway span thirteen years of interactions and visits with informants on the estate. During this time it became apparent that both the children and adults 
were not only willing and happy to discuss a whole range of sensitive issues regarding child sex offenders and grooming, they were 'excited' and 'relieved' that someone from the 'outside' world wanted to listen. This provided a 'voice' to young people who live in marginalised and excluded communities, who are 'disproportionately the victims of crime and other life trauma' (Yates, 2004: 27); which is also a common theme in child abuse victims (see Berliner and Conte, 1990: 35-36). The data collected and used here has been linked to the broader research into child sexual victimization and grooming literature, which highlighted an important aspect that needed further investigation: what types of behaviours happen during the grooming period and how can these be identified as grooming behaviours.

Unfortunately, this type of ethnographic research throws up all sorts of ethical challenges and dilemmas. Some of these dilemmas include potentially mixing legality with illegality; causing harm to respondents; deceit; professional disrepute; and potential danger to the researcher (Bourgois, 2002; Ferrell and Hamm, 1998; Hobbs, 2007; Inciardi et al, 1993; Tunnell, 1998; Winlow et al, 2001; Yates, 2004). My primary concern was to ensure respondents anonymity and the protection of children. To this end, consent forms were used that did not contain any information that could identify the respondents and the identification list was kept in a location that only I knew about. The ethics procedure of the university where I was based during the initial research was followed, and consisted of the British Sociological Association and British Society of Criminology ethical codes of conduct. Only children who were able to provide informed consent were interviewed, and with the full agreement and consent of their parents and/or guardians and grandparents. All children under the age of 16 were interviewed in the presence of a parent or grandparent and followed the procedures set out in similar research into child sexual grooming (e.g. Berliner and Conte, 1990). These interviews consisted of discussions about 'grooming stories'; or to put it another way, of grooming 'experiences' and 'narratives' from those who had direct contact with confirmed child sexual offenders. 'It is important to note that I consciously avoided asking any direct questions about sexual abuse experienced by the children themselves. However, it should be noted that if any of the interviewees had disclosed abuse, I would have provided help and guidance to the relevant parent or guardian regarding their options for reporting and dealing with the alleged abuse. Fortunately, this situation did not occur.

\section{Child Grooming Stories}

This section introduces examples of the types of grooming behaviours that are typical to those children who have experienced interactions with child sex offenders. Whilst strong inferences and generalisations should not be attached to this data, the evidence does highlight key themes and commonalities in grooming behaviours that are identified in other research studies (e.g. Berliner and Conte, 1990; Elliott et al, 1995; Finklehor, 1984; McAlinden, 2002).

\section{"Got Your Ears On"}

The first case study concerns a male (AB) aged approximately 53 who had a preference for young/adolescent teenage boys (see Williams, 2004; Williams and Thompson 2004a and 2004b; Thompson and Williams, 2014: 211-241). This particular individual had a long history of previous convictions, one of which included a nine-year prison sentence for being part of a gang who 
committed offences against more than 100 boys, many of whom had learning difficulties. In 1996 a national tabloid (25.08.96) ran an exclusive on $A B$ in which he claimed that no child was safe and that it would only take ten minutes to get a child for sexual purposes. He further explained that he 'targeted boys aged 11 or 12 ' as that was the age where children have 'primitive urges to experiment with sex'. He also noted that this was the age when children were 'most vulnerable to men like me'. AB claimed that in his previous offending there was 'no premeditation' and that he was an 'opportunist'; however, his distal planning clearly falls within the covert/implicit type identified by Ward et al (1995), as evidenced by practices such as taking a 'pushbike to a park', installing a ' $C B$ radio in his Datsun' and sitting with a ' $C B$ outside his home'. $A B$ created these situations in order to enhance the likelihood of contact with a child; and he was often very successful at exploiting the natural curiosity of children.

$A B$ had arrived on the estate from another southern coastal town after a flat swap with a tenant from the estate. He came to the research site sometime in late 1998 or early 1999 and proceeded to integrate into the local community. It should be noted that at the time AB moved onto the estate, multi-agency public protection arrangements (MAPPA) were in their infancy and local authorities did not have strict monitoring procedures in place (Kemshall, 2010; Maguire and Kemshall, 2004: 209224; Nash and Williams, 2008: 103-130; Williams, 2004: 378-392). Local authorities began to formalise such arrangements in 2001, due to the statutory requirements laid down in sections 67-69 of the Criminal Justice and Court Services Act 2000 (Williams, 2004: 378-392). At the very outset then, the presence of a capable supervisor, whether it was in the form of a 'handler' of the offender, or 'manager' of the crime setting was practically non-existent (Felson, 2008: 74-75). This allowed AB free rein to set-up the requisite conditions for grooming.

Once on the estate, $A B$ began two grooming strategies. The first involved grooming the environment and significant others (Craven et al, 2006: 292-294), which was an attempt to overcome external inhibitors (Finkelhor, 1984), through front-staging a 'hard-luck' narrative (Goffman, 1990). He started attending coffee mornings at a local club where many parents and grandparents used to 'hang-out' after taking the children to school, and acted as a social meeting place frequented by many residents throughout the day. His front-stage narrative consisted of a story he told to local residents that he was divorced and his ex-wife refused him access to his children, which elicited sympathy especially amongst the mothers and grandmothers (Female 1). He had an allotment on which he grew vegetables and handed them out to the families he knew best; and to those residents who had direct contact with him, everything appeared normal:

We sat drinking tea (with $A B$ ) in the G Club Fridays. We've let him on the estate: he come around as a really nice person. He spoke well, and you could have a laugh and a joke with him. I mean he had an allotment, he grew veg, and he was good enough to invite some of the women down. He did come over as a nice person, a really nice person (Female 1).

Such behaviour follows van Dam's (2001 cited in Craven et al, 2006: 293) finding that offenders are frequently charming, very helpful, and have insider status, and which gains the trust of families (Elliott et al, 1995: 585). In terms of time frame, AB s grooming of the local environment and significant others took place for approximately 18 months. He was patient and strategic and targeted those families, especially women, where he perceived vulnerabilities to exist (e.g. easygoing, hospitable and with teenage boys, such as Family 2). Previous research has found that 
offenders become experts at identifying vulnerable children and families (Berliner and Conte, 1990: 35; Elliott, 1995: 584-588). AB's grooming practices took place along his and the residents routine activity nodes (i.e. residences, shops, by schools and the local cafe/club) (Brantingham and Brantingham, 2008: 78-93). What is particularly interesting in this respect, is that whilst $A B$ was able to groom certain environmental areas and significant others, there was another group of residents who knew of $A B$ s offending past, and who had complained to the council almost as soon as he moved onto the estate, stating that he was a 'risk to children' (Female 11). Despite this he still maintained his grooming practices as group A (those being groomed) never spoke to Group B (the 'knowledgeables'), stopping only when he was identified in a Sunday tabloid (Williams, 2004: 303309). This highlights the difficulties in identifying grooming behaviours that do not consist of overt sexual acts (e.g. verbal and physical contact) and which take place whilst the offender is 'hiding in plain sight'. The patient manipulation of a number of residents was a crucial factor in gaining access to victims, which leads to the second grooming strategy undertaken by $A B$.

$A B^{\prime}$ s grooming of children on the estate follows similar behavioural patterns found in the research on the sexual grooming of children; especially in the areas of creating the circumstances for contact with a potential victim and the buying of gifts and treats (Berliner and Conte, 1990: 31-34; Craven et al, 2006: 292-296; Elliott et al, 1995: 583-586; McAlinden, 2012: 94-146). As with his past behaviours, the $C B$ strategy was used to instigate seemingly 'innocent' contact with children, which he met through grooming the families. Using the $C B$ in his flat $A B$ contacted a teenager (Male 6) of one family, who happened to have the same interest in the communication device. This contact started going into $A B^{\prime}$ 's flat. Soon after his brother, (Male 5) started 'going down to the flat' and this became a regular occurrence (Female 4; Female 1; Female 5). With the benefit of hindsight respondents noted that this was an effective way to attract the attention of a broad range of children: 'that was how he was attracting them, with his CB' (Female 1). As the 'trust' built up, other children started 'hanging-out' at the flat. Offenders will often use victims to recruit other children into their homes (Elliott et al, 1995: 584) and $A B$ exploited this by using other grooming techniques such as buying the children sweets, alcohol, cigarettes and video games. Female 1 explains this aspect to $A B$ 's behaviour:

Well I knew for a fact that he'd been buying 'em presents. He'd bought (Male 5) a mobile phone and he buys 'em phone cards. He was just buying 'em things, things for their computers (Female 1).

In this respect, Female 4 explains an interesting dynamic of this type of offender-victim interaction:

Well, they was going down there, they was getting things with him; and 'cause they're kids, really if they're given anything that they can't buy their selves, kids will love it, won't they?

The enticement of 'freebies' is a typical and effective strategy for child sex offenders to use when grooming, especially if the child comes from the poorer end of the socio-economic scale (Berliner and Conte, 1995: 35-36). It is important to acknowledge that whilst $A B$ was able to interact with children through the grooming of families, he also targeted those he did not know, by enticing some children to enter his home with the promise of 'treats', as illustrated by the parents of another young male: 
Yeah but he did say to us he went down there. He went into the hallway didn't he, and the bloke said to him "oh I've got cigarettes in here" (Female 5); and he said he had games (Male 3); (he said) "video...erm...computer games that you can play on". But it never even crossed me mind, you know, computer games: it never crossed me mind about this bloke's a paedophile (Female 5).

This example highlights what McAlinden (2012: 95-96) calls 'forbidden fruit' activities, which includes items that are technically illegal for children to use/consume such as alcohol, cigarettes and drugs, the showing of pornography (adult and/or child) or the telling of dirty jokes. The 'deviant' nature of these acts is used to make children 'more compliant' and reduce the likelihood that they disclose such activities to their parents. In the case of Female 5 and Male 3, their son only told them he had been in AB's flat after 'an incident' where he lost his coat escaping out of a window. The stories from parents, grandparents and children leads to the conclusion that over a two year period $A B$ had set up a multi-layer, complex web of grooming the environment, significant others and children. Soon after he was identified as a CSO, AB sent a text Male 5 informing him that what the papers and 'gossips' on the estate were saying about him wasn't true and asked Male 5 to meet with him to explain his side of the story. Fortunately, Male 5 declined. As the aftermath of the demonstrations died down, the government made a number of promises that through the newly created MAPPA arrangements, the monitoring of child sex offenders would improve dramatically. I returned to the estate on average every two months of every year since August 2000 to see if that was indeed the case.

\section{Just Cuddling}

The second case study involves a category 1 offender who was 'beaten-up' by the father of a 14/15 year-old girl after he found out his daughter was 'hanging-out' at the home of a known 'sex offender'. He also discovered that she was drunk and 'being cuddled' by the male who was aged approximately 43 years old (Female 1; Female 15). ${ }^{\text {iii }}$ This case illustrates the difficulties in policing grooming when there exists an increased likelihood for interactions between the potential offender and victim and an absence of handlers and guardians. The victim criteria for grooming in this case were teenage girls aged between 13-15, with a group of around 6 girls 'hanging-out' in the home over a period of up to 2 years. ${ }^{\text {iv }}$ The adult male in question had been supplying the girls with vodka and cigarettes and gave one of the group keys to his flat. Female 15 noted how the girls often ended up drunk, with Russian Vodka being the drink of choice. She also admitted that pictures had been taken of the girls dancing whilst drunk, although she did stress that these pictures were not sexual in nature. However, it cannot be discounted that they were not used for masturbatory fantasies or sold to collectors at a later point (Taylor and Quayle, 2003; O Donnell and Milner, 2007). A number of aspects of this case are interesting. First is the way the 'groomer' controlled the environment. He refused to allow 'boys' in the flat, and if they came 'and knocked the door' he would take a knife, threaten them and ask the boys to leave (Female 1; Female 15). This signifies gender preference as suggested in the research by Elliott et al, 1995: 581). Second, one of the girls involved (Female 16) had known the male since she was a small child, which explains why it was her group of friends that began spending so much time in the flat. This pattern of grooming follows the acquaintance offender who builds up trust to establish a social and then intimate relationship with the victim (Elliott et al, 199: 581; McAlinden, 2012: 92). Female 16 admitted 'cuddling' the offender but what was even more worrying was that one of her friends (Female 17) 'started sleeping round a week after her $16^{\text {th }}$ 
birthday' (Female 15). When the father of Female 16 found out that his daughter had been drunk in the flat cuddling a 43 year-old male, he dished-out his own form of rough justice and physically attacked the male involved. The police and paramedics were called to his residence where a crowd had gathered and this is where a member of the public overheard the police officer say (rather loudly) to the paramedic that he was a 'category 1 offender' (Female 1). It was also suggested by Female s 1, 15 and 18 that it was known that the police and wardens were 'watching kids going into the flat' for a number of weeks prior to the offender being attacked. This individual was relocated and when I visited the flat with Females 1, 15 and 18 the police had placed a notice in the window stating that the occupant was no longer living there. When discussing this it was suggested it was put there to stop the local children 'doing the windows' (Female 1).

This case illustrates a number of important issues relating to child sexual grooming. These girls were vulnerable due to their age and family circumstances and the 'groomer' was aware of this and exploited it to his advantage. Furthermore, Females 16 and 17 came from families where supervision from 'a capable guardian' (Felson, 2008: 74-75) was either relaxed or non-existent, creating increased opportunities for the 'groomer' to interact with potential victims (Berliner and Conte, 1990: 35-36).

\section{Spending Time}

The final case study involves a serious of 'events' where a number of children had been attending a house where two known sex offenders were living. As with the first two case studies, this was happening over an extended period of time (for 'approximately 2 years', according to Male 8 ). The 'offenders' in question were aged 46 and 51 (The News, 08.10.12), and the victim criteria were young boys aged 10-14, although on a few occasions female friends of the boys were also present. Similar to many other cases, the two 'groomers' offered 'freebies' (Female 1; Male 8) in the form of cups of tea and manipulated their interest in mechanics and cars. This took the form of involving the children in fixing the 4 cars and 1 van owned by the males residing at the property (Male 8 ). The 'forbidden fruits' strategy followed similar patterns found in the other grooming narratives collected in the wider research (Berliner and Conte, 1990; Elliott et al, 1995; Canter et al, 1998; Craven et al, 2006; McAlinden, 2006 and 2012). In this case, the use of beer, cigarettes and drugs, with many of the males going to the house to 'smoke weed' (Male 8). These are attractive enticements to some young children, especially those at the stage where they are developing their 'experiences' with deviant activities such as alcohol and drugs. What should be highlighted in this case, however, was the condition placed on the children that in order to get the 'forbidden fruits' they 'had to spend a little time' with the occupants (Male 8). Whether this was because of real 'loneliness' or for some 'ulterior' motive cannot be confirmed. However, the fact that the males were arrested for the sexual assault and rape of a child under 16 provides strong inferential evidence towards the latter.

There were a number of other 'rules' that the children had to abide by in order to gain access to the treats being handed out. They were told that 'if someone "knocks-the-door" they had to run out of the back door' (Female 1 and Male 8). Secondly, they were only allowed upstairs if accompanied by one of the adults (Male 8). Finally, they were not allowed on the computer (Male 8), which could indicate that the 'groomers' did not want the children finding inappropriate content on the computer. This explanation makes sense given the fact that one of the adults was on bail after police found thousands of indecent images of children on his computer (see The News, 08.10.12). 
Furthermore, to expose children immediately to child pornography could run the risk of destroying the rapport and trust they had built-up and end the possibility of abuse. This is why offenders tend to use more subtle strategies during the initial grooming process, for example, telling dirty jokes, conversations about sex and perhaps showing the children adult pornography (McAlinden, 2012: 9596).

Male 8 noted that he witnessed and knew of 'lots of males dropping-in' and that some 'often slept in the house'. He said that 'they do "buckets" and there are lots of (motor) bikes, grass and cannabis' and admitted that it was a fun place to 'hang-out'. He spoke of the time where some of the children were taken over to a field in W, were given weed and 'there was a "rave" in the back of the van'. He admitted that he been attending the house to drink beer, smoke cigarettes and weed yet stopped 'hanging-out' when it was insisted that he 'spend time' with the occupants which he felt uncomfortable doing. As with the other cases used in this study the 'groomers' used another child (a male aged approximately 13-14 years old) to introduce other children to the house. This child appears to have been a 'foot-solider' for the offenders. In 2011, the two adult males took an 11year-old male to a field in location $\mathrm{F}$ and allegedly raped him. The local newspaper reported on the criminal trial, with the jury finding one of the males guilty of sexual assault, but acquitted both males of rape. One male found guilty received a 4-year custodial sentence (The News, 08.10.12).

\section{Conclusion}

One of the biggest challenges facing criminal justice agencies is that child sexual grooming is often identified only after an abusive episode and with the benefit of hindsight. This is because the grooming behaviours that are typical for this group of offenders are often innocuous acts that masquerade as friendship and interest in the child, family and local community. Understanding the grooming period between initial contact and the eventual sexual abuse is important, as it allows us to see changes that take place in the offender-victim relationship and in the largely hidden area where the relationship changes from stranger to acquaintance. The ethnographic stories presented here are important for they provide a micro-level context to these offender-victim interactions and provide an insight into the behavioural patterns of child sex offenders (Canter and Youngs, 2009).

The patterns of behavioural-consistency between individuals grooming children on the estate follow those found in the literature (e.g. Berliner and Conte, 1990; Canter et al, 1998; Craven et al, 2006; Elliott et al, 1995; McAlinden, 2006 and 2012) and include: identifying the most vulnerable children (i.e. based on age, family structure, and 'socially excluded' factors such as economic means); grooming of the environment and significant others; and providing a place to 'hang' where those being 'groomed' are enticed by the offer of gifts (e.g. computer games and mobile phones) and 'forbidden fruits' (e.g. alcohol, cigarettes and drugs). Whilst the offender-victim interaction evidence presented in this article should not be exaggerated or distorted, it should at the very least raise concerns that many of the cases discussed above (and many more uncovered during the research) involve offenders who are known to the local authorities and/or are being managed and monitored by police and probation agencies. These offenders are still able to groom children over extended periods of time and more needs to be done to protect the most vulnerable and marginalised in society. There is a clear identifiable pattern of grooming behaviour with individuals targeting young children who are approaching or have gone through puberty, or are adolescents. These victims have 
fewer restrictions and less supervision on their movements, and are at the stage of their lives where they are 'experimenting' with forbidden fruits. When this is supplemented by gifts that they or their families might not be able to afford, it enables the groomers to develop relationships and exploit their targets' vulnerabilities (Berliner and Conte, 1990: 35-36). By understanding this micro-level context of offender-victim grooming interactions, we enhance our understanding of grooming strategies and practices, which can be used to identify preparatory acts that could be used as 'redflags' by criminal justice agencies to impose sanctions on the groomers (e.g. by applying for $\mathrm{ROHO} / \mathrm{SOPOs}$ or instigating breach proceedings). Unfortunately, the difficulties in proving 'harmful intent' identified by Ost (2004) and McAlinden (2012) will remain unless early identification of grooming behaviours can be linked to an offender's known MO. The fact that seemingly innocent behaviours tend to be used alongside illegal preparatory behaviours (i.e. under-age drinking and drug-taking) could be a way around the legal barrier of proving 'harmful ulterior intent'. However, caution and proportionality must be applied if interventions are to be applied. There is a danger that with recent attention and funding directed towards Internet grooming and child sexual exploitation cases, we ignore the types of grooming that occur on a daily basis in our local communities.

\section{References}

Adler, P. A. and Adler, P. (1998). Forward: moving backward. In J. Ferrell and M. S. Hamm (Eds.). Ethnography at the edge: crime, deviance, and field research, pp. xii-xvi. Boston: Northeastern University Press.

APA (1994). DSM-IV-TR: diagnostic and statistical manual of mental disorders. Washington, DC: American Psychiatric Press Inc.

Armstrong, G. (1998). Football hooligans: knowing the score. Oxford: Berg.

Atkinson, P., Coffey, A., Delamont, S., Lofland, J. and Lofland, L. (Eds.). (2007). Handbook of ethnography. London: Sage Publicans Ltd.

Bartol, C. R. and Bartol, A. M. (2008). Criminal behaviour: a psychosocial approach (8th ed.). New Jersey: Pearson Education Inc.

Becker, H. (1953). Becoming a marijuana user. American Journal of Sociology, 59(3), pp. 235-242.

Becker, H. (1963). The outsiders: studies in the sociology of deviance. New York: The Free Press.

Becker, H. (1967). Whose side are we on? Social Problems, 14(3), pp. 239-247.

Beech, A. R., Craig, L. A. and Browne, K. D. (Eds.). (2009). Assessment and treatment of sex offenders: a handbook. Chichester: Wiley-Blackwell.

Bell, V. (2002). The vigilant(e) parent and the paedophile: the News of the World campaign 2000 and the contemporary governmentality of child sexual abuse. Feminist Theory, 3(1), pp. 83-102. 
Berelowitz, S. (2013). If only someone had listened: The Office of the Children's Commissioner's inquiry into child sexual exploitation in gangs and groups final report. London: Office of the Children's Commissioner.

Berliner, L. and Conte, J. R. (1990). The process of victimization: the victims perspective. Child Abuse and Neglect, 14(1), pp. 29-40.

Best, J. (Ed.). (1995). Images of issues: typifying contemporary social problems. New York: Aldine De Gruyter.

Best, J. (Ed.). (2001). How claims spread: cross-national diffusion of social problems. New York: Aldine De Gruyter.

Bourgois, P. (2002). In search of respect: selling crack in El Barrio (2 ${ }^{\text {nd }}$ ed.). Cambridge: Cambridge University Press.

Brantingham, P. and Brantingham, P. (2008). Crime pattern theory. In R. Wortley and L. Mazerolle (Eds.). Environmental criminology and crime analysis, pp. 78-93. Cullompton: Willan Publishing.

Canter, D., Hughes, D. and Kirby, S. (1998). Paedophilia: pathology, criminality, or both? The development of a multivariate model of offence behaviour in child sexual abuse. The Journal of Forensic Psychiatry, 9(3), pp. 532-555.

Canter, D., Alison, L. J., Alison, E. and Wentink, N. (2004) The organized/disorganized typology of serial murder: myth or model? Psychology, Public Policy, and Law, 10 (3). pp. 293-320.

Canter, D. and Youngs, D. (2009). Investigative psychology: offender profiling and the analysis of criminal action. Chichester: John Wiley and Sons Ltd.

CEOP (2011). Out of mind, out of sight: breaking down the barriers to understanding child sexual exploitation. London: Child Exploitation and Online Protection Centre.

Cohen, S. (2003). Folk devils and moral panics (3rd Ed.). Oxford: Blackwell Publishers.

Craven, S., Brown, S. and Gilchrist, E. (2006). Sexual grooming of children: review of literature and theoretical considerations. Journal of Sexual Aggression, 12(3), pp. 287-299.

Denzin, N. (197 1). The logic of naturalistic inquiry. Social Forces, 50(2), pp. 166-182.

Elliott, M., Browne, K. and Kilcoyne, J. (1995). Child sexual abuse prevention: what offenders tell us. Child Abuse and Neglect, 19(5), pp. 579-594.

Evans, J. (2003). Vigilance and vigilantes: thinking psychoanalytically about anti-paedophile action. Theoretical Criminology, 7(2), pp. 163-189.

Felson, M. (2008). Routine activity approach. In R. Wortley and L. Mazerolle (Eds.). Environmental criminology and crime analysis, pp. 70-77. Cullompton: Willan Publishing.

Ferrell, J. and Hamm, M. S. (Eds.). (1998). Ethnography at the edge: crime, deviance, and field research. Boston: Northeastern University Press. 
Finkelhor, D. (1984). Child sexual abuse: new theory and research. New York: Free Press.

Furedi, F. (1997). Culture of fear: risk-taking and the morality of low expectation. London: Cassell.

Gobo, G. (2008). Doing ethnography. London: Sage Publications Ltd.

Goffman, E. (1990). The presentation of self in everyday life. London: Penguin Books Ltd.

Hobbs, D., Hadfield, P., Lister, S. and Winlow, S. (2003). Bouncers: violence and governance in the night-time economy. Oxford: Oxford University Press.

Hobbs, D. (2007). Ethnography and the study of deviance. In P. Atkinson, A. Coffey, S. Delamont, J. Lofland and L. Lofland (Eds.). Handbook of ethnography, pp. 204-219. London: Sage Publicans Ltd.

HOCHAC (2013). Child sexual exploitation and the response to localized grooming. Second report of session 2013-14, volume I: report, together with formal minutes. London: The Stationery Office Limited.

Holmes, S. T. and Holmes, R. M. (2008). Sex crimes (3rd ed.). Thousand Oaks, CA: Sage Publications Inc.

Howitt, D. (1995). Paedophiles and sexual offences against children. Chichester: John Wiley and Sons Ltd.

Hudson, K. (2005). Offending identities: sex offenders' perspectives on their treatment and management. Cullompton: Willan Publishing.

Inciardi, J. A., Lockwood, D. and Pottiger, A. E. (1993). Women and crack cocaine. Upper Saddle River, NJ: Prentice-Hall Inc.

Ireland, J. L., Ireland, C. A. and Birch, P. (2009). Violent and sexual offenders: assessment, treatment and management. Cullompton: Willan Publishing.

Janus, E. S. (2006). Failure to protect: America s sexual predator laws and the rise of the preventive state. Ithaca: Cornell University Press.

Jenkins, P. (2003). Beyond tolerance: child pornography on the Internet. New York: New York University Press.

Kemshall, H. (2010). Community protection and multi-agency public protection arrangements. In M. Nash and A. Williams (Eds.). The handbook of public protection, pp. 199-216. Oxon: Willan Publishing.

Kemshall, H. and Wood, J. (2010). Child sex offender review (CSOR) public disclosure pilots: a process evaluation $2^{\text {nd }}$ edition. London: Home Office.

Kitzinger, J. (1999). The ultimate neighbour from hell? Stranger danger and the media framing of paedophiles. In B. Franklin (Ed.). Social policy, the media and misrepresentation, pp. 207-221. London: Routledge. 
Kitzinger, J. (2004). Framing abuse: media influence and public understanding of sexual violence against children. London: Pluto Press.

Liebow, E. (1967). Tally's corner: a study of negro streetcorner men. Boston, MA.: Little Brown.

Liebow, E. (1993). Tell them who I am: the lives of homeless women. London: Penguin.

Lyng, S. (1998). Dangerous methods: risk taking and the research process. In J. Ferrell and M. S. Hamm (Eds.). Ethnography at the edge: crime, deviance, and field research, pp. 221-251. Boston: Northeastern University Press.

Maguire, M. and Kemshall, H. (2004). Multi-agency public protection arrangements: key issues. In H. Kemshall and G. Mclvor (Eds.). Managing sex offender risk, pp. 209-224. London: Jessica Kingsley Publishers.

Marshall, W. L. and Barbaree, H. E. (1990). An integrated theory of the etiology of sexual offending. In. W. L. Marshall, D. R. Laws and H. E. Barbaree (Eds.). Handbook of sexual assault: issues, theories, and treatment, pp. 257-275. New York: Plenum Press.

McAlinden, A. (2006). 'Setting 'em up': personal, familial and institutional grooming in the sexual abuse of children. Social \& Legal Studies, 15(3), pp. 339-362.

McAlinden, A. (2012). 'Grooming' and the sexual abuse of children: institutional, Internet, and familial. Oxford: Oxford University Press.

Nash, M. (2006). Public protection and the criminal justice process. Oxford: Oxford University Press. Nash, M. and Williams, A. (2008). The anatomy of serious further offending. Oxford: Oxford University Press.

Nash, M. and Williams, A. (Eds.). (2010). Handbook of public protection. Oxon: Willan Publishing. O'Donnell, I. and Milner, C. (2007). Child pornography: crime, computers and society. Cullompton: Willan Publishing.

Ost, S. (2004). Getting to grips with sexual grooming? The new offence under the Sexual Offences Act 2003. Journal of Social Welfare and Family Law, 26(2), pp. 147-159.

Phoenix, J. (2012). Out of place: the policing and criminalisation of sexually exploited girls and young women. London: The Howard League for Penal Reform.

Polsky, N. (1971). Hustlers, beats and others. Harmondsworth: Penguin.

Prentky R. A., Knight, R. A. and Lee, A. F. S. (1997). Child sexual molestation: research issues. NCJ 163390. Washington, DC: US Department of Justice.

Qualye, E. and Ribisl, K. M. (Eds.). (2012). Understanding and preventing online sexual exploitation of children. Oxon: Routledge.

Scott, P. D. (1977). Assessing dangerousness in criminals. British Journal of Psychiatry, 131, pp. 127142. 
Seto, M. C. (2007). Pedophilia and sexual offending against children: theory, assessment and intervention. Washington, DC: American Psychological Association.

Shaw, C. R. (1966). The Jack-Roller: a delinquent boy s own story. Chicago: The University of Chicago Press.

Sheldon, K. and Hewitt, D. (2007). Sex offenders and the Internet. Chichester: John Wiley \& Sons Ltd. Silverman, J. and Wilson, D. (2002). Innocence betrayed: paedophilia, the media and society. Cambridge: Polity Press.

Stevenson, K., Davies, A. and Gunn, M. (2004). Blackstone's guide to The Sexual Offences Act 2003. Oxford: Oxford University Press.

Sutherland, E. H. (1956). The professional thief. Chicago: The University of Chicago Press.

Taylor, M. and Quayle, E. (2003). Child pornography: an Internet crime. Hove: Brunner-Routledge.

Thomas, T. (2011). The registration and monitoring sex offenders: a comparative study. Oxon: Routledge.

Thompson, E. P. (1993). Customs in common: studies in traditional popular culture. London: Routledge.

Thompson, B. and Williams, A. (2014). The myth of moral panics: sex, snuff and Satan. New York: Routledge.

Tunnell, K. D. (1998). Honesty, secrecy, and deception in the sociology of crime: confessions and reflections from backstage. In J. Ferrell and M. S. Hamm (Eds.). Ethnography at the edge: crime, deviance, and field research, pp. 206-220. Boston: Northeastern University Press.

Wacquant, L. (2009). Punishing the poor: the neo-liberal government of social insecurity. Durham, NC: Duke University Press.

Ward, T., Louden, K., Hudson, S. M. and Marshall, W. L. (1995). A descriptive model of the offense chain for child molesters. Journal of Interpersonal Violence, 10(4), pp. 452-472.

Ward, T., Polaschek, D. L. L. and Beech, A. R. (2006). Theories of sexual offending. Chichester: John Wiley \& Sons Ltd.

Ward, T. and Siegert, C. A. (2002). Towards a comprehensive theory of child sexual abuse: a theory knitting perspective. Psychology, Crime and Law, 9, pp. 319-351.

Whyte, W. F. (1995). Street corner society: the social structure of an Italian slum (2nd Ed.). Chicago: The University of Chicago Press.

Williams, A. (2004). 'There ain't no peds in Paulsgrove': social control, vigilantes and the misapplication of moral panic theory. Unpublished PhD Thesis, University of Reading, Reading, UK.

Williams, A. and Thompson, B. (2004a). Vigilance or vigilantes: the Paulsgrove riots and policing paedophiles in the community. Part I: the long slow fuse. The Police Journal. 77(2), pp. 99-119. 
Williams, A. and Thompson, B. (2004b). Vigilance or vigilantes: the Paulsgrove riots and policing paedophiles in the community. Part II: the lessons of Paulsgrove. The Police Journal. 77(3), pp. 199205.

Williams, A. (2006). Paedophiles, panics, and protests: understanding penal populism. Japanese Journal of Sociological Criminology, 31, pp. 52-72.

Winlow, S., Hobbs, D., Lester, S. and Hadfield, P. (2001). Get ready to duck: bouncers and the realities of ethnographic research on violent groups. British Journal of Criminology, 41(3), pp. 536548.

Wortley, R. and Mazerolle, L. (Eds.). (2008). Environmental criminology and crime analysis. Cullompton: Willan Publishing.

Wyre, R. (1997). Working with sex offenders. Oxford: Perry Publications.

Yates, J. (2004). Criminological ethnography: risks, dilemmas and their negotiation. British Journal of Community Justice, 3(1), pp. 19-31.

Zott, L. M. (Ed.). (2008). Sex offenders and public policy. Farmington Hills, MI: Greenhaven Press.

\footnotetext{
' Confirmation was made by reviewing court day sheets, case results reported in local newspapers as well as general Internet newspaper searches.

ii The age range denotes the fact that these grooming events occurred for over a year and that the exact age when the grooming started and continued is difficult to confirm.

iii Observation and interview notes, 20.08.10.

iv Observation and interview notes, $16.08 .10 ; 20.08 .10$.
} 